\title{
SOCIO-DEMOGRAPHIC DETERMINANTS OF HEALTH-RELATED LIFESTYLE AND SELF-ASSESSMENT OF HEALTH IN WOMEN
}

\author{
Małgorzata Kazimiera Dziedzic ${ }^{\mathrm{A}, \mathrm{B}, \mathrm{D}}$, Małgorzata Dziubak ${ }^{\mathrm{B}, \mathrm{E}}$, Dorota Matuszyk ${ }^{\mathrm{C}, \mathrm{F}}$, Elżbieta Sibiga ${ }^{\mathrm{C}, \mathrm{E}}$
}

Laboratory of Fundamentals in Obstetric Care, Institute of Nursing and Midwifery,

Faculty of Health Sciences, Jagiellonian University Medical College, Krakow, Poland

Authors' contribution:

A. Study design/planning $\bullet$ B. Data collection/entry $\bullet$ C. Data analysis/statistics $\bullet$ D. Data

interpretation $\bullet$ E. Preparation of manuscript $\bullet$ F. Literature analysis/search $\bullet$ G. Funds collection

\author{
Address for correspondence: \\ Małgorzata Kazimiera Dziedzic \\ Laboratory of Fundamentals in Obstetric Care \\ Institute of Nursing and Midwifery \\ Faculty of Health Sciences \\ Jagiellonian University Medical College \\ 58 Zamoyskiego St. \\ 31-523 Krakow, Poland \\ e-mail: malgorzata.dziedzic@uj.edu.pl \\ SUBMITTED: 08.12.2019 \\ ACCEPTED: 20.12.2019 \\ DOI: https://doi.org/10.5114/ppiel.2019.92541
}

\begin{abstract}
Introduction: Lifestyle is recognised as a key determinant of human health, and at the same time is subject to modification. When women enter the menopausal and postmenopausal periods they are prone to the occurrence of many diseases. A healthy lifestyle can improve the quality of life in women during menopause and the onset of old age. Aim of the study: To assess the sociodemographic characteristics of lifestyle and health self-assessment of women over 45 years of age in the population of the city of Krakow.

Material and methods: The research used the diagnostic survey method applying standardised tools. The Healthy Lifestyle Scale was utilised to collect data for the assessment of women's lifestyles. The Polish adaptation of the Nottingham Health Profile Questionnaire was used to examine health self-assessment. In total, 453 correctly completed questionnaires of randomly selected women collected between 2015 and 2016 were qualified for the analysis.

Results: The study confirmed that women with higher education and better financial status are more likely to lead a healthy lifestyle. Health self-assessment is highest among the youngest of the surveyed age groups, among working professionals, and women who are married or in a partnership, as well as the respondents with higher education. Conclusions: The conducted research indicates that the choices made by women regarding healthy lifestyles are highly unsatisfactory and largely dependent on sociodemographic characteristics. It is necessary to take measures to modify the health behaviours and quality of life of women due to insufficient compliance with recommendations. Key words: lifestyle, menopause self-evaluation of health.
\end{abstract}

\section{INTRODUCTION}

In the World Health Organisation (WHO) strategy, the term "lifestyle" designates a way of life based on the mutual relationship between living conditions in a broad sense, and individual behavioural patterns, determined by socio-cultural factors and individual characteristics [1]. Such an assessment indicates that it is the personal daily decisions and behavioural patterns that largely determine the state of one's health, and thus the quality of life. If an individual's daily routine includes health-promoting behaviours, commonly known as pro-health behaviours, it is referred to as a healthy lifestyle that protects, sustains, or extends their health potential [2, 3].

The variables determining a health-promoting lifestyle, which are significant for both sustaining health and life expectancy include: adequate nutrition, physical activity, adequate quality and dura- tion of sleep, avoidance of stress and coping with it, safety-oriented behaviours in daily life, safe sexual life, absence of tobacco consumption, limited use of alcohol, non-abusive use of unprescribed medicines or psychoactive substances, health self-control and self-examination of various aspects of health, and personal hygiene. The variables mediating health behaviours include gender, age, current health situation, financial situation, education, type of occupation, behaviour standards, health behaviour standards, the system of values, the level of family stability and social support, personality traits, and possession of clear goals [3, 4].

The sense of health is a basic factor in the quality of life, closely related to an individual's lifestyle. In women over 45 years of age, entering the transition phase between the reproductive period and the beginning of aging, the occurring hormonal changes 
of the menopause cause many adverse metabolic and atrophic changes in tissues, fostering the occurrence of many diseases. The increase in the number of women in the perimenopausal period means that the experiences related to its symptoms concern not only women but also become a visible and significant social problem. Hormonal changes manifesting in the body of menopausal women are detrimental to the quality of their lives, which begins to result in decreased vitality, a reduction in the level of physical and social activity, and even withdrawal from social life [5]. A healthy lifestyle can improve the quality of life in women during menopause and the onset of old age, delaying the involution processes that occur in the body, affecting positively the incidence and course of chronic diseases that often accompany this stage of life.

\section{AIM OF THE STUDY}

The objective of the study was to assess the lifestyle and health self-assessment of women over 45 years of age in the population of the city of Krakow and to identify to what extent the selected socioeconomic characteristics have an impact on health behaviour and health self-assessment.

\section{MATERIAL AND METHODS}

The research used the diagnostic survey method applying standardised tools. To collect data assessing women's lifestyles the Healthy Lifestyle Scale developed by Corbin et al., was utilised. It allows assessment of the proportion of particular behaviours included in good or bad lifestyles from the point of view of their health-related consequences [6]. The individual behaviours measured by the questionnaire were classified into 10 categories of lifestyle behaviours. The greatest weight was assigned to categories in the field of physical activity, nutrition, stress control, and avoidance of unhealthy habits. The Polish adaptation of the Nottingham Health Profile (NHP) Questionnaire created by British researchers: Hunt, McEwan, and McKenna was used to examine self-assessed health. The Polish adaptation of NHP was developed by Wrześniewski [7]. The scale consists of two parts, the first of which comprises 38 statements, which are assigned to six dimensions (domains) related to the subjective assessment of health. They concern feelings of vitality, pain, emotional reactions, sleep disorders, social isolation/alienation, and mobility limitations. The results are calculated according to the number of positive responses within a given domain, and the numbers - weights are added together. This amount cannot exceed 100 in each domain. The result of this calculation is subtracted from 100, and the result of the subtraction is divided by 100 , which gives a number between 0 and 1 , where 0 means the most adverse health situation, and 1 means a state of well-being [7].

Survey questionnaires were distributed among randomly selected respondents by post after obtaining the consent of the Bioethics Committee of 27.02.2014 KBET/28/B/2014 in the period from 2014 to 2016. In total, 453 correctly completed questionnaires were qualified for the analysis.

The particular measured elements were interpreted, and then the impact of the selected socioeconomic variables on lifestyle and self-assessment of health was analysed.

\section{RESULTS}

In the first part of the lifestyle analysis the proportion of the surveyed women who engage in positive behaviours was assessed in the particular categories included in the studied lifestyle. The first of the areas of the analysed lifestyle - physical activity recommended by the WHO - was maintained by $30.2 \%$ $(n=137)$ of the respondents.

$35.5 \%$ of the surveyed women followed the principles that qualify their diets as compliant with the most important nutrition recommendations. This meant that these women regularly consumed at least three meals a day, choosing food products in accordance with the recommendations of the health pyramid, while limiting the amount of fat in their diets and making allowances for the energy value of the diets following their needs.

Almost half of the women, $49.4 \%(n=224)$, stated that they could control stress by being able to recognise stressful situations, devoting time to relaxing and pleasurable activities, and reducing tension.

$60.9 \%(n=276)$ of the respondents avoided unhealthy habits such as nicotine consumption, alcohol abuse, and abusive usage of medicines, including those available without a prescription. $41.5 \%$ ( $n=188$ ) of women described themselves as being able to provide first aid, which was defined as having undergone training in this area and at the same time being able to perform the Heimlich manoeuvre. $49.2 \%(n=223)$ of the participants adopted health habits related to e.g. adequate sleep duration and teeth hygiene, while $64.9 \%$ followed their doctors' instructions $(n=294)$. Adherence to the principles of safe sex was confirmed by $61.6 \%$ of the surveyed women. They declared having a permanent "safe" partner or refraining from having dangerous sex and acknowledged using methods to protect against sexually transmitted diseases.

$82.1 \%(n=372)$ of the respondents complied with recommendations regarding the use of seat belts, adherence to speed limits for vehicles, and ownership and controlling the operation of smoke detectors in 
their apartments. $87.6 \%(n=397)$ of the respondents considered themselves to be concerned about environmental protection, applying measures such as segregation of waste, conservation of energy, and avoidance of polluting the surroundings.

Out of 453 respondents the proportion of women whose lifestyle could be qualified as good equalled $9.5 \%$; this was the proportion of respondents that included the general proportion of positive behaviours in all the categories of lifestyle aspects that were studied.

The group of surveyed women was diverse in terms of socio-economic characteristics. Several socio-economic variables were chosen to study the relationship between lifestyle and these characteristics: age, education, net income per family member, professional status, and marital status.

Two of the socioeconomic variables selected for the analysis were found to have an impact on the lifestyle of the surveyed women. The proportion of respondents leading a healthy lifestyle was higher among women with higher education, amounting to $13.9 \%$, while in women with secondary and postsecondary education it was $8.2 \%$, and in women with vocational and elementary education it was $3.8 \%$ $(p=0.0280)$ (Figure 1).

Income level was another socioeconomic variable that was demonstrated to be statistically significant $(p=0.0362)$ in differentiating women's lifestyles into correct and incorrect ones. Analysis of the results showed that $15.2 \%$ of women in the group with net income above PLN 2001 per person in the family led a healthy lifestyle, the proportion of respondents with an income of PLN 1001-2000 and leading a healthy lifestyle was $9 \%$, and in the group with an income of up to PLN 1000 it was 6.1\% (Figure 2).

\section{WOMEN'S HEALTH SELF-ASSESSMENT}

Among the six studied domains of subjective assessment of health status, women most often indicated abnormalities manifested in sleep disorders, reaching the level of 0.70 and abnormalities in vitality reaching 0.74 . Social isolation almost does not apply to the study group, because the overall result in this domain is 0.90 and it is the highest among health aspects assessed in individual domains. Also, mobility received high results and amounted to 0.89 . Women assessed their emotional responses at the level of 0.83 ; pain sensations were also low - a result of 0.81 was obtained in this domain.

\section{Age group and health self-assessment}

The analysed relationships showed that age (considered in three age groups) statistically significantly

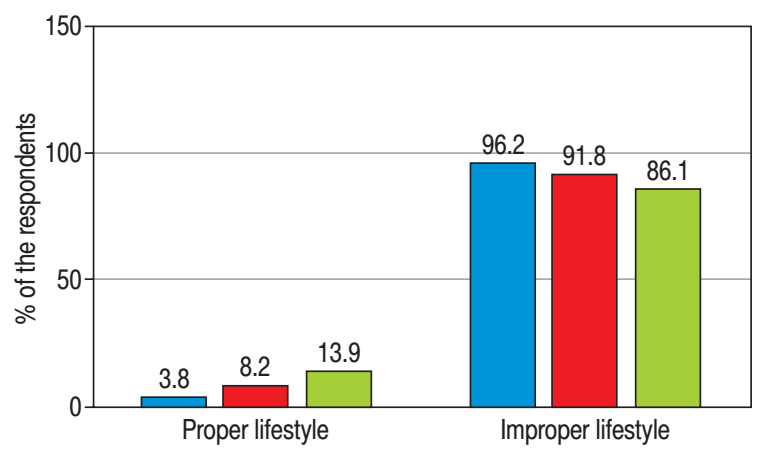

\section{$\square$ Elementary and vocational \\ $\square$ Secondary and post-secondary \\ $\square$ Higher/University}

Figure 1. Women's lifestyles depending on education. Statistically significant differences $p=0.0280$

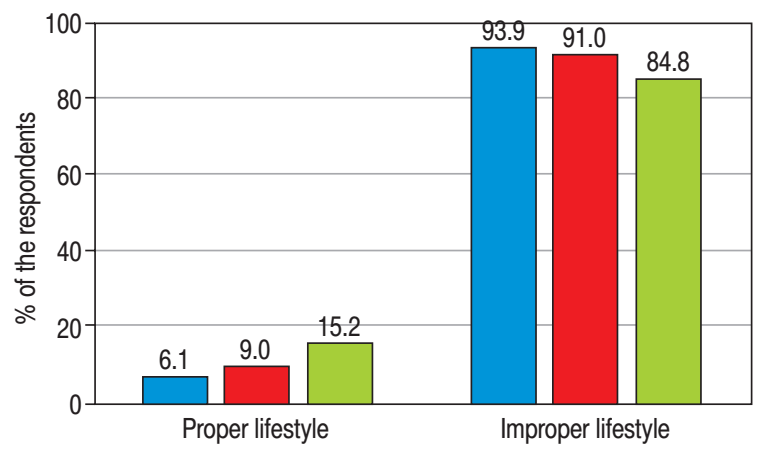

$\square$ Income PLN 1000 and lower

$\square$ Income PLN 1001-2000

$\square$ Income PLN above 2001

Figure 2. Women's lifestyle depending on income. Statistically significant differences $p=0.0362$

differentiated self-assessment of health in all surveyed domains ( $p<0.0001)$.

The assessment of vitality was higher in the 45-55-year-old age group than the result obtained from women over 65 years of age. Pain sensations were the lowest in the youngest age group. Negative emotional reactions were experienced more often by the oldest surveyed women compared to both younger age groups: $45-55$ years old and $56-65$ years old. The self-assessment of sleep disorders worsened with age, the group aged 45-55 years experienced the it the least, it intensified among women 56-65 years old, reaching the greatest advancement among the oldest respondents. The sense of social isolation concerned all studied groups to a small extent, and a difference in its perception was observed between two younger age groups of women vs. the oldest group. The younger age groups rated their mobility better than did the oldest of the studied groups (Table 1). 
Table 1. Results of women's health self-assessment surveyed with the Nottingham Health Profile Questionnaire depending on the age group

\begin{tabular}{|c|c|c|c|c|c|c|c|}
\hline \multirow{2}{*}{$\begin{array}{l}\text { Health } \\
\text { self-assessment } \\
\text { domains }\end{array}$} & \multicolumn{2}{|c|}{$\begin{array}{c}\text { Age } 45-55(\mathrm{~A}) \\
n=232\end{array}$} & \multicolumn{2}{|c|}{$\begin{array}{c}\text { Age } 56-65 \text { (B) } \\
n=141\end{array}$} & \multicolumn{2}{|c|}{$\begin{array}{c}\text { Age } 65+(C) \\
n=80\end{array}$} & \multirow[t]{2}{*}{$p$} \\
\hline & $X \pm S D$ & Me (min-max) & $\mathrm{X} \pm \mathrm{SD}$ & Me (min-max) & $X \pm S D$ & Me (min-max) & \\
\hline Vitality & $0.77 \pm 0.28$ & $1(0-1)$ & $0.78 \pm 0.32$ & $1(0-1)$ & $0.57 \pm 0.38$ & $0.63(0-1)$ & $\begin{array}{c}<0.0001 \\
\text { AC, BC }\end{array}$ \\
\hline Pain & $0.88 \pm 0.20$ & $1(0-1)$ & $0.81 \pm 0.25$ & $0.90(0-1)$ & $0.60 \pm 0.29$ & $0.67(0-1)$ & $\begin{array}{c}<0.0001 \\
A B, A C\end{array}$ \\
\hline Emotional reactions & $0.86 \pm 0.20$ & $1(0.16-1)$ & $0.83 \pm 0.22$ & $0.90(0-1)$ & $0.74 \pm 0.25$ & $0.84(0.09-1)$ & $\begin{array}{c}<0.0001 \\
\text { AC, BC }\end{array}$ \\
\hline Sleep disorders & $0.79 \pm 0.29$ & $0.87(0-1)$ & $0.67 \pm 0.33$ & $0.87(0-1)$ & $0.50 \pm 0.34$ & $0.44(0-1)$ & $\begin{array}{c}<0.0001 \\
A B, A C, B C\end{array}$ \\
\hline Social isolation & $0.94 \pm 0.17$ & $1(0-1)$ & $0.89 \pm 0.21$ & $1(0-1)$ & $0.81 \pm 0.29$ & $1(0-1)$ & $\begin{array}{c}<0.0001 \\
A C\end{array}$ \\
\hline Mobility & $0.94 \pm 0.11$ & $1(0.46-1)$ & $0.90 \pm 0.16$ & $1(0.21-1)$ & $0.72 \pm 0.22$ & $0.69(0.21-1)$ & $\begin{array}{c}<0.0001 \\
A C, B C\end{array}$ \\
\hline
\end{tabular}

Differences between groups (post-hoc test for Kruskal-Wallis test) $A$ - age 45-55 years, $B$ - age 56-65 years, $C$ - age $65+$ years, $N$ - number of women, $X$ - arithmetic mean, $S D$ - standard deviation of point values, Me - the median, min - minimum, max - maximum, $p$ - materiality level, $A B, A C$, $B C$ - statistically significant correlation between groups

Table 2. Results of women's health self-assessment surveyed using the Nottingham Health Profile questionnaire depending on the type of education

\begin{tabular}{|c|c|c|c|c|c|c|c|}
\hline $\begin{array}{l}\text { Health } \\
\text { self-assessment } \\
\text { domains }\end{array}$ & \multicolumn{2}{|c|}{$\begin{array}{c}\text { Elementary and vocational } \\
\text { education (A) } \\
n=79\end{array}$} & \multicolumn{2}{|c|}{$\begin{array}{c}\text { Secondary and post- } \\
\text { secondary education (B) } \\
n=207\end{array}$} & \multicolumn{2}{|c|}{$\begin{array}{l}\text { Higher/University } \\
\text { education (C) } \\
n=165\end{array}$} & $p$ \\
\hline Vitality & $0.65 \pm 0.38$ & $0.76(0-1)$ & $0.74 \pm 0.32$ & $1(0-1)$ & $0.79 \pm 0.27$ & $1(0-1)$ & $>0.05$ \\
\hline Pain & $0.71 \pm 0.29$ & $0.77(0-1)$ & $0.81 \pm 0.25$ & $0.90(0-1)$ & $0.87 \pm 0.21$ & $1(0-1)$ & $\begin{array}{c}<0.0001 \\
A B, A C\end{array}$ \\
\hline Emotional reactions & $0.76 \pm 0.26$ & $0.86(0-1)$ & $0.84 \pm 0.21$ & $0.90(0.09-1)$ & $0.86 \pm 0.20$ & $1(0.19-1)$ & $\begin{array}{c}0.0065 \\
A C\end{array}$ \\
\hline Sleep disorders & $0.58 \pm 0.36$ & $0.62(0-1)$ & $0.70 \pm 0.32$ & $0.87(0-1)$ & $0.77 \pm 0.29$ & $0.87(0-1)$ & $\begin{array}{l}0.0005 \\
A B, A C\end{array}$ \\
\hline Social isolation & $0.84 \pm 0.26$ & $1(0-1)$ & $0.91 \pm 0.19$ & $1(0.16-1)$ & $0.91 \pm 0.21$ & $1(0-1)$ & $>0.05$ \\
\hline
\end{tabular}

Differences between groups (post-hoc test for Kruskal-Wallis test) $A$ - elementary and vocational education, $B$ - secondary and post-secondary education, $C$ - higher/university education, $N$ - number of women, $X$-arithmetic mean, SD - standard deviation of point values, Me - median, min-minimum, max-maximum, $p$-materiality level, $A B, A C$ - statistically significant correlation between groups

\section{Education and health self-assessment}

The analysed relationships showed that education statistically significantly differentiates self-assessment of health in as many as four domains in such a way that at the lowest education level these assessments are the lowest. The analysis of the assessment of the degree of pain sensation showed that it was experienced most in the group of women with the lowest education. The women with elementary and vocational education coped with emotions to a much lesser extent than the group of women with post-secondary and higher education.

The highest severity of sleep disorders occurred in the group of women with the lowest education (elementary and vocational). The women with the lowest education felt more limited in their mobility in comparison to the women with undergraduate and higher education. The level of assessed vitality and social isolation turned out to be independent of their education (Table 2).

\section{The level of income and health self-assessment}

The level of income statistically significantly differentiated two domains of health self-assessment: vitality and emotional reactions.

Vitality was assessed the lowest by women in the group with the lowest income (up to PLN 1000 net per family member), at $0.70 \pm 0.33$, and the highest in the group with the highest income (above PLN 2001), 
at $0.84 \pm 0.26$. This relationship was determined at a statistically significant level $p=0.0013$. The same level of emotional reactions was found in the group of women with income up to PLN 1000 and in the group with income PLN 1001-2000; $0.81 \pm 0.24$ vs. 0.81 \pm 0.22 . The women with the highest financial status were able to cope with emotional responses much better than the other groups. The estimated level in this group was $0.88 \pm 0.19$. The differences between these assessments showed statistical significance, $p=0.0045$. Differences in assessment levels in the other domains: pain level, sleep disorders, social isolation, and mobility did not show statistical significance related to the level of income.

\section{Professional status and health self-assessment}

Occupational status considered in two categories: working women and non-working women differentiated self-assessment of health in all domains, except for pain levels. Working women assessed their vitality higher compared to inactive women $(0.78 \pm 0.28$ vs. $0.66 \pm 0.38 ; p=0.0303$ ). Non-working women experienced pain more than the group of women working professionally ( $0.86 \pm 0.21$ vs. $0.71 \pm 0.29$; $p<0.0001)$.

Sleep disorders were more common in inactive women than in working women $(0.71 \pm 0.29$ vs. 0.60 \pm 0.35 ; $p<0.0001$ ). Similarly, social isolation was more frequently experienced by the first of these groups compared to the active group ( $0.92 \pm 0.18$ vs. 0.85 \pm 0.26 ; $p=0.0068$ ). When analysing mobility limitations, it should be stated that their occurrence in the group of non-working women was much higher than in the group of women working professionally $(0.93$ \pm 0.12 vs. $0.80 \pm 0.22 ; p<0.0001)$. In the assessment of emotional reactions, no statistically significant relationship was found between the group of working and non-working women.

\section{Marital status and health self-assessment}

The health self-assessment of married women was statistically significantly higher in all the studied domains compared to the self-assessment of unmarried women.

Married women assessed their vitality significantly higher compared to unmarried women $(0.79 \pm 0.29$ vs. $0.66 \pm 0.35 ; p=0.0004)$. The assessment of pain sensations in both groups was varied, to the disadvantage of single women, who struggled with these ailments more ( $0.85 \pm 0.23$ vs. $0.75 \pm 0.28$; $p=0.0001$ ).

Adverse emotional reactions were more frequently experienced by single women compared to married women ( $0.86 \pm 0.18$ vs. $0.78 \pm 0.26$; $p=0.097$ ).

Sleeping disorders were experienced less by married women than by single women $(0.75 \pm 0.29$ vs. 0.61 \pm 0.36 ; $p<0.0001$ ). Married women experienced very little social isolation, while it was more common for single women ( $0.95 \pm 0.14$ vs. $0.82 \pm 0.28$; $p<0.0001)$.

More mobility limitations were related to single women compared to the married respondents (0.91 \pm 0.15 vs. $0.84 \pm 0.20 ; p=0.0003$ ).

\section{DISCUSSION}

In light of existing reports about the proven impact of lifestyle factors on human health, it is important to know to what extent care for sustaining health is attributable to menopausal, postmenopausal, and older women, increasingly referred to as geriopausal women. The analysis of the discussed research showed that only $9.5 \%$ of them had a lifestyle in which the level of compliance with recommended behaviours was considered satisfactory. Having analysed four criteria for a healthy lifestyle among more than 1200 people aged 20-64 years (absence of tobacco consumption, adequate consumption of fruit and vegetables, sufficient physical activity, and normal body weight) Kwaśniewska et al. showed that only $6.1 \%$ of women fulfilled these conditions [8]. The research conducted by Kózka et al. among the residents of Kraków and the surrounding area showed that only $5 \%$ of women met the assumed criteria of a healthy lifestyle [9].

In the discussed research, the level of those following a healthy lifestyle was the highest among the group with higher education. The 2010 CEBOS research shows that those who care about their health are more often respondents with higher education and those who earn the highest income [10]. The analysis of the discussed results showed that $15.2 \%$ of women in the group with income above PLN 2001 had a healthy lifestyle, with less than half of this value $(6.1 \%)$ among the women with income below PLN 1000 per person in the family.

When analysing the impact of individual lifestylerelated behaviours on health, it should be recognised that not all of them pose the same risk to sustaining health. Some of them can have an almost immediate negative impact on health, e.g. tobacco or drug consumption. Awareness of first aid procedures may have an occasional influence on health. The factors with particularly positive, scientifically proven impact on sustaining health are physical activity, proper nutrition, the ability to control stress, and avoid harmful habits such as tobacco use, drug, and alcohol abuse. Therefore, when assessing the lifestyles, it was important to analyse the behaviours of the studied women in each category of lifestyle behaviours.

Sources indicate that proper nutrition is an important determinant of health, which is particularly important in relation to elderly people [19]. It is a stage 
of life in which improper nutrition increases the risk of developing chronic non-communicable diseases or aggravating existing ones. The aging process of the body is irreversible; it takes place at a different pace depending on many conditions among which diet is an important factor, independent and additional to classical factors determining this process, as well as the severity of disease occurrence. A proper diet during this period of life may delay the progression of age-related chronic diseases [11].

In the discussed study, proper nutrition could be found in $35.5 \%(n=161)$ of women. Comparing this result with the results of the study of proper nutrition principles conducted by Gacek in a group of Krakow women aged 60-86 years, it should be stated that Gacek's research indicated a lower proportion of respondents who follow these principles. Comparing the findings of subsequent authors, it should be stated that nutritional errors are consistently confirmed in studies. Research on the nutritional behaviour of people over 60 years of age in Krakow carried out by Gabrowska and Spodaryk also showed significant irregularities, especially in the selection of products according to the healthy diet pyramid [12].

A positive correlation between better socioeconomic status, i.e. education and income, with a greater variety of consumed food was demonstrated in research carried out in a group of over 400 people aged over 65 years by Niedźwiecka and Wądołowska [13]. The relationship found by the authors is also consistent with the findings of other authors [14].

A greater degree of dietary variety in people with a higher socioeconomic status can be explained by the possibility of incurring greater expenditure on food. In contrast, older people care more about rational nutrition, most likely due to having more free time and for health reasons.

The basis of the latest version of the healthy diet pyramid, in accordance with WHO guidelines, is physical activity. Physical activity, along with proper nutrition, is the most important factor assessed in the context of a healthy lifestyle. Exercise not only helps sustain healthy body weight but also reduces the risk of developing many chronic diseases. The discussed research showed that this principle is followed by $30.2 \%$ of women. It was declared more often by women who were not professionally active compared to those working professionally. Low compliance was also shown by research carried out by Biernat and Piątkowska among over 1.5 thousand respondents between 18 and 64 years of age [15]. The NATPOL 2011 studies point out that although $60 \%$ of Poles declare physical activity, only in $32 \%$ of them refer to almost daily activity [16].

We can expect a clear impact of physical activity on health only if it is continued systematically.
Regular physical activity helps to sustain a healthy body weight or fight obesity, which at the same time increases the sense of attractiveness, improves the psychophysical condition, and reduces ailments of the menopause [17].

There are few studies in our country regarding the physical activity of adult Polish women, especially in the postmenopausal period. The conducted research concerns specific regions of the country, or selected cities or professional groups. The varied standards used for assessing physical activity in these analyses constitute a considerable difficulty in comparing the results.

Among the sociodemographic characteristics, professional and financial status turned out to have a positive impact on the ability to cope with stress. The ability to control stress was more common among non-working women compared to those who were professionally active and for women with the best financial status.

In the study by Kózka et al. [9] cited earlier, it was shown that stress was controlled by only $5 \%$ of the respondents, and it is one of the most frequently mentioned causes of increased incidence of many civilisation diseases.

The study results related to preventive behaviour show some convergence with the results obtained by Kutkowska and Kierzenkowska [17]. Kózka et al. in their research conducted in a group of 76 women from Kraków, aged $45-60$ years, showed that only $42 \%$ of the surveyed population have regular check-ups, including breast self-exam [9]. The quoted results and comparisons indicate that too few women regularly monitor their health in the period of life when they are especially at risk of oncological diseases.

Avoidance of harmful habits such as tobacco and alcohol consumption was found in the discussed study in $60.9 \%$ of women, and they were more often women with higher education. Thus, the remaining approx. $40 \%$ should be considered as individuals consuming tobacco and alcohol, with a lower or higher frequency. The results of research conducted in 2013 for GIS (Chief Sanitary Inspector) among the adult population of the country indicated that $23 \%$ of women consumed tobacco, and, similarly to the results mentioned above, it showed that the most frequent tobacco consumers were, apart from young adults, the group aged 50-59 years with vocational education [18].

The results of the health self-assessment obtained in the discussed research for all surveyed women are different for particular dimensions. The lowest value, i.e. the worst results, were obtained for such areas as sleep difficulties and vitality, and the best were in the area of social alienation and mobility difficulties. The middle values regard self-assessment of pain sensations and emotional reactions. These results are con- 
sistent with those demonstrated by Wróblewska on the basis of data from the Pentor Opinion and Market Research Institute obtained in 2005 from a representative sample of 4017 people in Poland, where the assessments of the levels of sleep disorders and vitality in women over 18 years of age were also the lowest among all domains studied [19].

The discussed research compared the self-assessment of health of the surveyed women depending on some socioeconomic characteristics, i.e. age, education, marital status, and financial status. The author demonstrated statistically significant differences in all domains of health self-assessment, depending on the age group selected for analysis. Health self-esteem decreases significantly with age. Comparable results, indicating the increase in health complaints with age, were obtained in studies of the previously cited Jachimowicz et al. The presented results are also consistent with those demonstrated by Loda and Muszlik, which confirm significantly more frequent occurrence of mobility limitations, pain, and sleep problems in correlation with age [20]. The results of research conducted by Jopkiewicz et al. among women over 40 years of age also confirm that the deterioration of health selfassessment correlates with older age [21].

In the discussed study, women with lower education, professionally inactive, and single report a higher level of pain, more severe sleep disorders, increased mobility limitations, and lower ability to deal with emotional reactions.

Respondents included in the group with the highest income report higher level of vitality and ability to cope with emotional responses compared to the average ratings of these elements of health self-assessment in women with the lowest and middle income.

Statistically significant relationships found in each of the components of health self-assessment confirmed the above conclusion. Comparable results demonstrating a correlation of health self-assessment and sociodemographic characteristics were found by research conducted among people aged over 65 years by Nowicki et al. [22].

The conducted research indicates that the choices among the surveyed women regarding healthy lifestyles are highly unsatisfactory, and it is necessary to take measures to promote behavioural changes towards their health. Raising health awareness and promoting health as one of the key elements in the hierarchy of human values are factors that can trigger the desired change in behaviour [23].

A midwife and a nurse may play a significant role in shaping the health behaviour of women in the menopausal period by strengthening the role and activity of women in all areas of health care, with particular emphasis on this group of recipients of medical services.

\section{CONCLUSIONS}

Women with higher education and better financial status are more likely to lead a healthy lifestyle.

The scope of the particular forms of health-related behaviours in the studied group is varied in such a way that health-critical behaviours, i.e. physical activity, proper nutrition, and stress control, constitute the lowest proportion of these behaviours.

Health self-assessment was highest in the youngest of the surveyed age groups, among working professionals, and women who were married/in partnership, as well as people with higher education.

Higher financial status is related, in the self-evaluation of health, with a higher level of perceived vitality and a lower level of negative emotional response.

\section{Disclosure}

The authors declare no conflict of interest.

\section{References}

1. Ostrowska A. Styl życia a zdrowie: Z zagadnień promocji zdrowia. Wyd. IFiS PAN, Warszawa 1999.

2. Gronowska-Senger A. Żywienie, styl życia a zdrowie Polaków. Żyw Czł 2007; 34: 602-606.

3. Elmadfa I, Meyer A, Nowak V, et al. European Nutrition and Health Report 2009. Forum Nutr 2009; 62: 1-405.

4. Dolińska-Zygmunt G. Behawioralne wyznaczniki zdrowia - zachowania zdrowotne. In: Dolińska-Zygmunt G (ed.). Podstawy psychologii zdrowia. Wyd. Uniwersytetu Wroctawskiego, Wrocław 2001; 33-70.

5. Skrzypulec V, Drosdzol A, Ferensowicz J, Nowosielski K. Ocena wybranych aspektów życia psychicznego i seksualnego kobiet w okresie okołomenopauzalnym. Gin Prakt 2003; 11: 23-34.

6. Corbin CB, Welk GJ, Corbin WR, Welk KA. Fitness i wellness. Kondycja, sprawność, zdrowie. Wyd. Zysk i S-ka, Poznań 2007.

7. Wrześniewski K. Badanie subiektywnego stanu zdrowia za pomocą polskiej adaptacji the Nottingham Health Profile. In: Karski JB, Kirschner H, Leowski J (eds.). Współczesne potrzeby i możliwości pomiaru zdrowia. Ignis, Warszawa 1997; 37-41.

8. Kwaśniewska M, Kaleta D, Dziankowska-Zaborszczyk E, et al. Lifestyle index and self-rated health status. Int J Occup Med Environ Health 2007; 20: 349-356.

9. Kózka M, Prażmowska B, Dziedzic M, Semczak M. Styl życia kobiet w okresie menopauzalnym - badania wstępne. Prz Med Uniw Rzesz Inst Leków 2013; 1: 61-74.

10. Komunikat z badań $\mathrm{nr} B S / 110 / 2012$. Polacy o swoim zdrowiu oraz prozdrowotnych zachowaniach i aktywnościach. CEBOS, Warszawa 2012.

11. Ribarič S. Diet and aging. Oxid Med Cellular Longev 2012: 741468.

12. Gabrowska E, Spodaryk M. Ocena sposobu żywienia osób starszych mieszkających w Krakowie. Żyw Człow Metab 2002; 29 (supl): 203-208.

13. Niedźwiecka E, Wądołowska L. Analiza urozmaicenia spożycia żywności w kontekście statusu socjoekonomicznego polskich osób starszych. Probl Hig Epidemiol 2010; 91: 576-584.

14. Drewnowski A, Darmon N, Brend A. Replacing fats and sweets with vegetable and fruits - a question a cost. Am J Public Health 2004; 94: 1555-1559. 
15. Biernat M, Piątkowska M. Zdrowotne rekomendacje Światowej Organizacji Zdrowia a rekreacyjna aktywność fizyczna Polaków. Med Sport 2013; 29: 255-264.

16. NATPOL 2011: Ponad połowa dorostych Polaków jest nieaktywna fizycznie. http://www.rynekzdrowia.pl/Uslugimedyczne/NATPOL-2011- (dostęp: październik 2015).

17. Kurkowska K, Kierzenkowska E. Poczucie koherencji a zachowania zdrowotne wśród kobiet w okresie menopauzalnym. Curr Ginekol Onkol 2014; 12: 206-215.

18. TNS Polska dla Głównego Inspektora Sanitarnego: Raport z ogólnopolskiego badania ankietowego na temat postaw wobec palenia tytoniu. TNS, Warszawa 2013.

19. Wróblewska W. Badanie jakości życia uwarunkowanej stanem zdrowia. In: Metodologia Badań Demograficznych. Poznań: Sekcja Analiz Demograficznych Komitetu Nauk Demograficznych PAN, Zielonka 2006; 79-92.

20. Loda M, Muszalik M. Jakość życia związana ze zdrowiem osób w starszym wieku. In: Krajewska-Kułak E, Szczepański M, Łukaszuk C, Lewko J (eds.). Problemy terapeutycznopielęgnacyjne od poczęcia do starości. Tom 1. AM w Białymstoku, Wydział Pielęgniarstwa i Ochrony Zdrowia, Białystok 2007; 385-393.

21. Jopkiewicz A, Gawron J, Majecka-Kotwica M. Charakterystyka wybranych elementów stylu życia osób dorosłych z województwa świętokrzyskiego. Zdr Dobrostan 2015; 2: 162-172.

22. Nowicki GJ, Młynarska M, Ślusarska B, et al. The self-assessment of health and its selected conditions within a group of over-65-year-old primary-care patients. J Edu Health Sport 2016; 6: 447-457.

23. Södergren M, Wang WC, Salmon J, et al. Predicting healthy lifestyle patterns among retirement age older adults in the WELL study: a latent class analysis of sex differences. Maturitas 2014; 77: 41-46. 